\title{
Diffuse glioma growth: a guerilla war
}

\author{
An Claes $\cdot$ Albert J. Idema $\cdot$ Pieter Wesseling
}

Received: 20 June 2007 / Revised: 23 August 2007 / Accepted: 23 August 2007 / Published online: 6 September 2007

(C) Springer-Verlag 2007

\begin{abstract}
In contrast to almost all other brain tumors, diffuse gliomas infiltrate extensively in the neuropil. This growth pattern is a major factor in therapeutic failure. Diffuse infiltrative glioma cells show some similarities with guerilla warriors. Histopathologically, the tumor cells tend to invade individually or in small groups in between the dense network of neuronal and glial cell processes. Meanwhile, in large areas of diffuse gliomas the tumor cells abuse pre-existent "supply lines" for oxygen and nutrients rather than constructing their own. Radiological visualization of the invasive front of diffuse gliomas is difficult. Although the knowledge about migration of (tumor)cells is rapidly increasing, the exact molecular mechanisms underlying infiltration of glioma cells in the neuropil have not yet been elucidated. As the efficacy of conventional methods to fight diffuse infiltrative glioma cells is limited, a more targeted ("search \& destroy") tactic may be needed for these tumors. Hopefully, the study of original human
\end{abstract}

A. Claes $(\bowtie) \cdot$ P. Wesseling

Department of Pathology,

Radboud University Nijmegen Medical Centre (RUNMC),

PO Box 9101, 6500 HB Nijmegen, The Netherlands

e-mail: a.claes@pathol.umcn.nl

\section{A. J. Idema}

Department of Neurosurgery,

Radboud University Nijmegen Medical Centre (RUNMC),

Nijmegen, The Netherlands

P. Wesseling

Nijmegen Center for Molecular Life Sciences,

RUNMC, Nijmegen, The Netherlands

P. Wesseling

Department of Pathology,

Canisius Wilhelmina Hospital,

Nijmegen, The Netherlands glioma tissue and of genotypically and phenotypically relevant glioma models will soon provide information about the Achilles heel of diffuse infiltrative glioma cells that can be used for more effective therapeutic strategies.
Abbreviations
Cdc Cell division cycle
CNS Central nervous system
CT Computerized tomography
CXCR4 Chemokine (C-X-C motif) receptor 4
ECM Extracellular matrix
EGF(R) Epidermal growth factor (receptor)
FAK Focal adhesion kinase
GBM Glioblastoma multiforme
HGF Hepatocyte growth factor
HIF Hypoxia inducible factor
MMP Matrix metalloproteinase
MRI Magnetic resonance imaging
NF- $\kappa$ B Nuclear factor kappa B
NSC Neural stem cell
PI3K Phosphatidylinositol 3-kinase
PTEN Protein phosphatase and tensin homolog
RGD Arginine-glycine-aspartic acid
SDF-1 Stromal cell-derived factor-1
SF Scatter factor
SPARC Secreted protein acidic and rich in cystein
uPA(R) Urokinase-type plasminogen activator (receptor)
VEGF Vascular endothelial growth factor
WHO World Health Organization

\section{Introduction}

Diffuse infiltrative gliomas are by far the most common primary brain tumors in adults, esp. its most malignant form, 
glioblastoma multiforme (GBM) [31]. In contrast to almost all other brain tumors, such diffuse gliomas are characterized by extensive, diffuse infiltration of tumor cells in the neuropil, i.e., the dense network of interwoven neuronal and glial cell processes. Based on the resemblance of the tumor cells with non-neoplastic glial cells, most diffuse gliomas are histopathologically typed as astrocytic, oligodendroglial, or oligoastrocytic [105]. Partly because of their growth pattern, curative treatment for diffuse gliomas is generally impossible. Although patients with low-grade [World Health Organization (WHO) grade II] diffuse gliomas may survive for multiple years, these tumors lead to death of the patient sooner or later, often after progression to high-grade (WHO grade III or IV) malignancy. Esp. in older age groups, diffuse gliomas frequently present as high-grade malignant lesions and carry a grim prognosis from the start. A subset of gliomas (e.g., ependymomas, pilocytic astrocytomas) shows a more circumscribed than diffuse infiltrative growth pattern, these latter gliomas will not be further discussed.

In the present review, we will first focus on the pathology of diffuse infiltrative glioma growth and its consequences for radiological diagnosis of these tumors. We will then systematically review the molecular mechanisms and factors that underlie this growth pattern (without trying to be complete) and discuss the implications for different therapeutic approaches. In the last part of this review we will touch on the limitations of in vitro and in vivo models for the study of diffuse infiltrative glioma growth. For other excellent recent reviews on (some of) these aspects we refer the reader to $[40,57,69,70,99,137,148,172]$. As diffuse infiltrative glioma cells show some similarities with guerilla warriors [130], we will use guerilla war as a metaphor for diffuse glioma growth throughout this manuscript in order to enhance the understanding of these tumors.

\section{Pathology}

Like guerilla warriors, in large areas of diffuse gliomas the tumor cells tend to invade individually or in small groups in "foreign" territory and to abuse pre-existent supply lines.

Diffuse infiltrative growth of tumor cells in the neuropil is almost unique for gliomas. Only very few non-glial tumors (esp. small cell lung carcinoma, lymphoma) occasionally display "pseudo-gliomatous" growth in the neuropil $[12,144,189]$. One of the pioneers in the study of glioma growth patterns is Hans-Joachim Scherer [129]. Scherer designated the arrangement of glioma cells that does not seem to depend on pre-existing tissue but can be considered as an expression of the intrinsic architectural potential of the tumor (e.g., canalicular structures, papillary formations) as "proper structures". Furthermore, he defined "secondary structures" as different patterns of arrangements of glioma cells that are considered to be dependent on preexisting tissue elements. Examples of secondary structures are perineuronal growth (perineuronal satellitosis), surface (subpial) growth, perivascular growth, and intrafascicular growth. "Tertiary structures" were defined by Scherer as formations brought about by the interaction of glioma cells with proliferating mesenchymal tissue of the tumor [157]. In diffuse gliomas, the cells preferentially invade along myelinated fibers in white matter tracts (intrafascicular growth), and subpial, perivascular, and perineuronal accumulation of tumor cells is frequently encountered [57] (Fig. 1). The most extreme example of diffuse infiltrative glioma growth is represented by gliomatosis cerebri. According to the WHO-2007 classification, this neoplasm involves at least three cerebral lobes, usually bilaterally, and even the entire neuraxis may be involved [36, 105, 111].

Recognition of diffuse infiltrative versus other types of glial tumors has significant prognostic and therapeutic implications. While the diffuse infiltrative growth pattern is characteristic for both low- and high-grade diffuse gliomas, esp. high-grade gliomas frequently show marked phenotypical heterogeneity with spatial differences in cellular phenotype and malignancy grade. Since molecular genetic studies demonstrated a common origin in different components of such heterogeneous diffuse gliomas, these tumors are considered as clonal lesions [17, 105]. The exact growth pattern of gliomas can not always be assessed in biopsy specimens, but histopathological features like intrafascicular growth, perineuronal satellitosis, and subpial accumulation of tumor cells strongly favor a diffuse infiltrative nature of the glial neoplasm.

In gliomas of high-grade malignancy, florid (often glomeruloid) microvascular proliferation and necrosis emerge. These changes, which are in fact used as histopathological criteria to diagnose high-grade malignancy in these tumors [105], are often spatially and temporally related. While high-grade gliomas may focally show an extreme angiogenic response, quantitative studies revealed that the vascular density in many regions of both low- and high-grade diffuse gliomas and of gliomatosis cerebri is in the range of that for normal cerebral grey or white matter, indicating that in large areas of these tumors angiogenesis is lacking [19, 191, 192]. In these latter areas, the diffuse infiltrative glioma cells seem to behave like guerilla warriors that do not construct their own supply lines but incorporate ("co-opt") and abuse pre-existent ones. Around areas of necrosis in high-grade gliomas the tumor cells often show pseudopalisading. Such perinecrotic cells were demonstrated to be less proliferative and have a higher apoptosis rate 


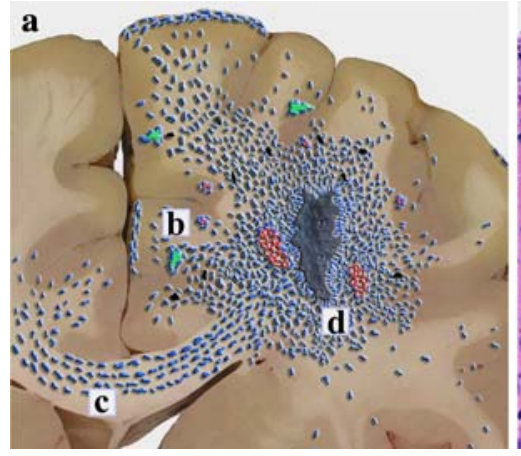

Fig. 1 Schematic representation of the growth pattern of a GBM (a), including the following secondary structures of Scherer: perivascular accumulation of tumor cells (example in area indicated by $b$; vessels in red, tumor cells in blue), perineuronal satellitosis ( $b$; neurons in green), subpial growth of tumor cells (b), and intrafascicular growth in the corpus callosum (c). Mitotic tumor cells are depicted in black. Furthermore, in GBMs necrosis (dark grey area) surrounded by pseudopalisading tumor cells and adjacent florid/glomeruloid microvascular proliferation (d) are often present. Images b-d on the right represent

than the tumor cells more distant from necrotic areas. The pseudopalisading cells also show increased expression of hypoxia inducible factor $1 \alpha$ (HIF- $1 \alpha)$ and vascular endothelial growth factor (VEGF), two factors that play a crucial role in the induction of angiogenesis $[22,23,49]$. There is evidence that the accumulation of tumor cells in the pseudopalisading zone is the result of migration of tumor cells away from the necrotic area [23]. Furthermore, it has been hypothesized that in this context necrosis selects for tumor cells that are more aggressive and more resistant to different therapeutic modalities [138].

Glioma cells can disseminate via white matter tracts, cerebrospinal fluid pathways, or meninges and thus give rise to multifocal gliomas. It is important to note that glioma growth in the subarachnoid/leptomeningeal compartment in itself does not imply malignant progression [105]. Despite the different ways of spread inside the CNS, extraneural metastases of diffuse gliomas are extremely rare and generally occur only after craniotomy or shunting [172]. A post mortem study investigating whole brain sections underscored that multifocal GBMs can emerge in the background of a better differentiated astrocytic neoplasm [26]. Multiple gliomas can occur as synchronous (diagnosed at initial presentation) and metachronous (appearing some time after initial diagnosis) lesions [89]. Widely separated glioma lesions that can not be attributed to the pathways just mentioned are called multicentric gliomas [11, 149]. Only a small percentage of glioma patients (estimated by some authors as $2 \%$ ) show multiple, seemingly independent lesions at initial presentation, most of these patients appear to have GBM $[10,11,149]$.

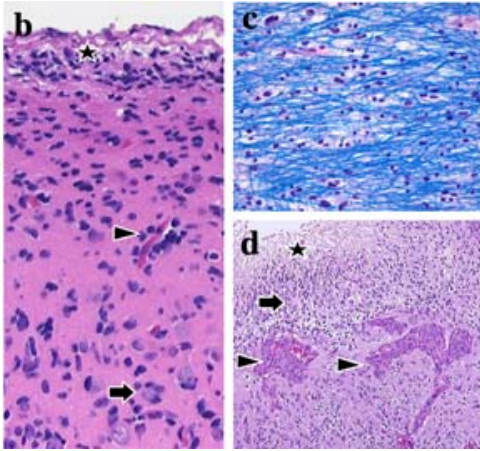

the histology of these features: in $\mathbf{b}$ asterisk indicates subpial growth, arrow indicates perineuronal satellitosis, arrowhead indicates perivascular accumulation of tumor cells; image $\mathbf{c}$ shows increased cellularity with diffuse infiltration of tumor cells in the relatively well preserved myelinated tracts of the corpus callosum; in image $\mathbf{d}$ asterisk indicates area of necrosis, arrow indicates peri-necrotic pseudopalisading tumor cells, arrowheads indicate glomeruloid microvascular proliferation [b, d: H\&E staining, c: combined Luxol Fast Blue and H\&E staining; original magnification $\times 200(\mathbf{b}, \mathbf{c})$ and $\times 100(\mathbf{c})]$

\section{Radiology}

Like in a guerilla war, visualization of the invasive front of diffuse infitrative gliomas is problematic.

Magnetic resonance imaging (MRI) is now the gold standard for defining brain tumor anatomy in a clinical setting [141]. Low-grade diffuse gliomas are typically hypointense lesions on T1-weighted MR images with limited edema and mass effect and lack of enhancement after the use of Gadolinium-DTPA [72]. On T2-weighted and FLAIR sequences low-grade diffuse gliomas are generally hyperintense. Discrimination of edema and infiltrating glioma is difficult using T1, T2, and FLAIR MR images. The lack of neovascularization and the apparently limited changes to the pre-existent, incorporated vessels explain the absence of contrast-enhancement in MRI examinations of these tumors [8]. As, according to the WHO-2007 classification [105], the main histopathological difference between WHO grade II and III diffuse astrocytic neoplasms is increased mitotic activity in the latter, it is not surprising that part of the non-enhancing diffuse gliomas are histopathologically diagnosed as high-grade lesions at the time of biopsy [8].

Compared to low-grade diffuse gliomas, high-grade tumors are often radiologically more heterogeneous and are accompanied by more severe edema. The occurrence of contrast-enhancement in diffuse gliomas generally signifies a more malignant biological behavior [8, 72, 141]. The extent of contrast-enhancement is influenced by the dosage of the contrast material [200]. The central area in "ringenhancing" high-grade diffuse gliomas most often represents necrosis, while the enhancing rim contains vital 
glioma tissue with microvascular changes including increased vascular permeability (Fig. 2). Some therapeutic interventions (e.g., surgical removal of glioma tissue, radiotherapy) may induce contrast-enhancement [166, 181]. Furthermore, it is important to note that contrast-enhancement in non-diffuse gliomas such as pilocytic astrocytomas does not implicate malignant progression.

Conventional radiological investigations tend to significantly underestimate the extent of diffuse infiltrative glioma growth. Correlation of whole brain histological sections of high-grade gliomas with computerized tomography (CT) scans revealed that tumor cells were present even outside the peritumoral areas of low density [27]. Compared with MRI, infiltrating glioma cells can be found beyond the hyperintensive region on T2-weighted images [43, 55]. As a consequence, radiological distinction between multifocal and multicentric gliomas can be challenging. Multifocal malignant progression in a diffuse glioma may radiologically result in multiple, seemingly independent, contrastenhancing lesions (Fig. 2). One study reported that using MRI, CT, or both, only in 12 out of 26 patients with multiple foci of glioma at initial diagnosis various patterns of spread were evident or suggested (subarachnoid > intraventricular $>$ direct brain penetration) [88].

New MR modalities may contribute to better radiological classification and delineation of glial brain tumors as well as assist in identification of the best spot for a biopsy [30]. With diffusion-weighted imaging (DWI) and a related approach called diffusion tensor imaging, differences in motility of water due to differences in cellularity, cell membrane permeability, intra- and extracellular diffusion, and tissue structure can be visualized. Theoretically, DWI can thus be used to image indirectly infiltration of glioma cells in normal brain tissue [30,96]. Perfusion weighted imaging (PWI) is a technique which allows for quantitative assessment of the cerebral blood volume (CBV). With PWI vascularization and perfusion of gliomas can be measured [192]. The (relative) CBV correlates with both vascularization and malignancy grade as assessed by histology. As long as tumor infiltration is accompanied by changes in vascularization and perfusion, PWI may also indirectly visualize the presence of infiltrating glioma cells [3, 78, 173]. Proton MR Spectroscopy (MRS) allows for obtaining metabolic spectra from (brain) tissue. Such spectra can be obtained in a single voxel or in multiple voxels in two or three dimensions $[9,176]$. These 2D and 3D approaches are also known as chemical shift imaging or MRS imaging (MRSI).

Several studies suggest that MRSI may be helpful for better delineation of diffuse gliomas [35, 55, 114, 132]. Combining different MR modalities (e.g., DWI, PWI, MRS) is expected to further improve these results [41, 135]. Up till now, a major drawback of most novel MR modalities is the limited spatial resolution: for conventional T1-weighted MRI at $3 \mathrm{~T}$ this resolution is about $0.5 \mathrm{~mm} \times 0.5 \mathrm{~mm} \times 0.5 \mathrm{~mm}$, while DWI and PWI reach a
Fig. 2 Examples of MR images in two glioblastoma patients. In patient 1 (a), the T1-weighted image reveals bifrontal Gadolinium enhancement of a tumor that crosses the corpus callosum (arrowhead), resulting in a so called "butterfly glioma". In the second patient $(\mathbf{b}-\mathbf{e})$, the T1-weighted images with (b, d) and without Gadolinium (c) suggest multiple, independent lesions. In the T2-weighted image (e), however, these bifrontal lesions appear to be interconnected via the corpus callosum (arrowhead), indicating that in this latter area disruption of the blood-brain barrier by infiltrating glioma cells is (still) limited.

$\mathbf{a}, \mathbf{b}$ : coronal plane; $\mathbf{c}-\mathbf{e}$ : axial plane
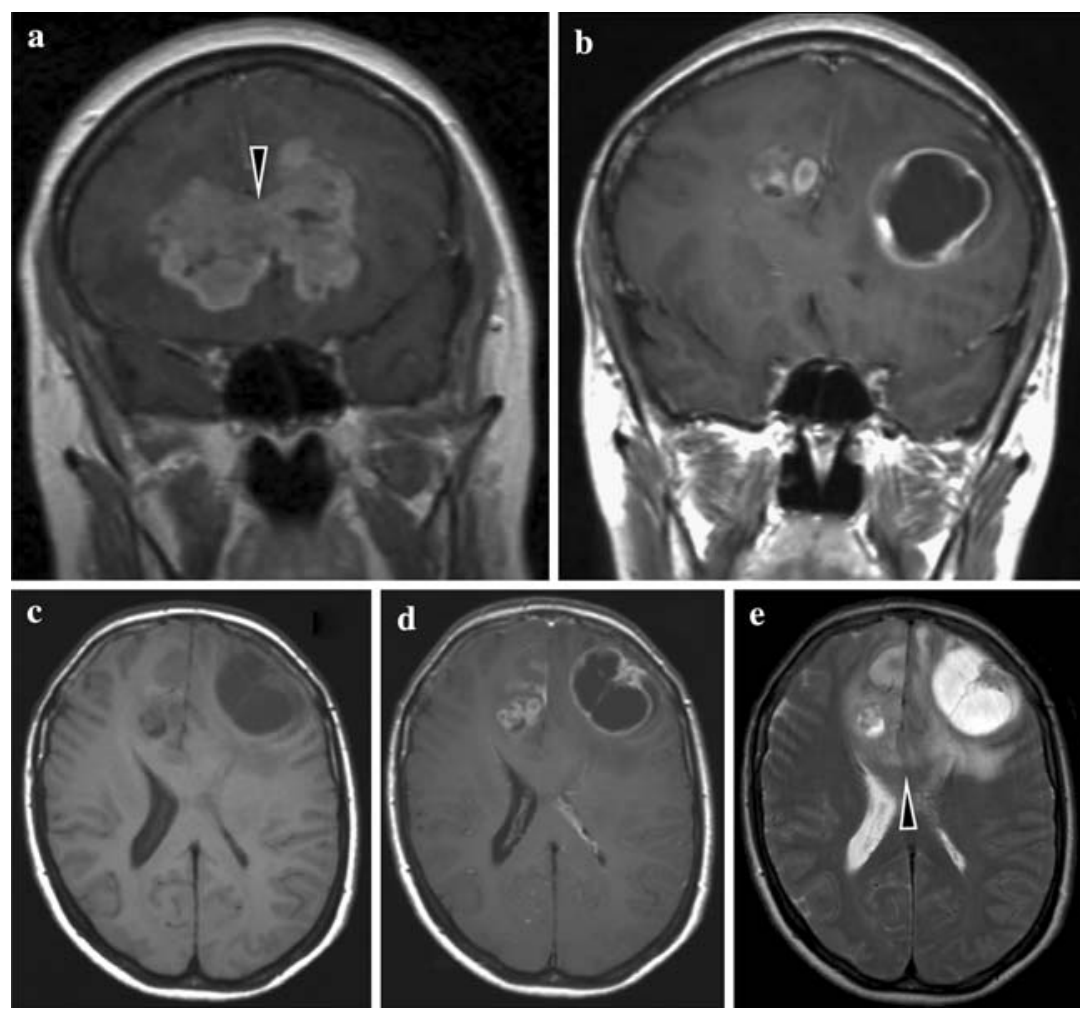
resolution of about $2 \mathrm{~mm} \times 2 \mathrm{~mm} \times 2 \mathrm{~mm}$, and MRS of $10 \mathrm{~mm} \times 10 \mathrm{~mm} \times 10 \mathrm{~mm}$. None of these new imaging techniques is expected to replace conventional MRI soon. Obviously, visualization of dispersed infiltrative glioma cells will improve when the technical development of these MR imaging modalities advances. Direct visualization of infiltrative glioma cells may also be performed by positron emission tomography (PET) and single photon emission CT (SPECT) imaging [16, 75, 106, 131]. Promising compounds for PET imaging of gliomas are O-(2-18F-fluoroethyl)-L-tyrosine [134] and 18F-Galacto-arginine-glycineaspartic acid (RGD), an $\alpha \mathrm{v} \beta 3$ binding molecule [71]. Furthermore, in the near future MR and PET imaging may be significantly improved by the application of nanoparticles $[18,82,184]$ and labelled antibodies [61].

\section{Molecular background}

\section{Like guerilla warriors, glioma cells posses specific qualities that allow for diffuse infiltration.}

The diffuse infiltrative growth of glioma cells in the neuropil warrants specific, tightly regulated and converging interactions between these cells and their microenvironment. Up till now it is not known what exactly initiates this behavior of glioma cells. As the group of diffuse gliomas is genotypically heterogeneous, it is unlikely that one particular genetic aberration accounts for this growth pattern in all diffuse gliomas. Several studies suggest that gliomas are derived from neural stem cells (NSCs) or glial progenitor cells rather than from derailed mature glial cells [54, 162, 199]. CD133 (Prominin-1) is frequently used as a marker for identification of NSC features in glioma cells, but other markers such as nestin, CD90, CD44, CXCR4, musashi homolog 1 (Msi1), and maternal embryonic leucine zipper kinase are also used for this purpose [6, 102]. Interestingly, in in vivo and in vitro experiments CD133-positive glioma cells displayed a greater tumorigenic potential than CD133negative cells, showed increased radio- and chemoresistance, and contributed in a major way to angiogenesis via VEGF production $[6,7,102,163]$.

During normal embryonic and fetal development of the CNS, extensive proliferation and migration of stem cells and progenitor cells is essential. In contrast, in the normal adult brain only in some locations (e.g., subventricular zone, hippocampus, dentate gyrus and sub-cortical white matter, rostral migratory system) some of these phenomena can still be present $[104,152]$. Clues for elucidation of the molecular mechanisms enabling diffuse infiltrative glioma growth may thus be provided by the rapidly expanding research focussing on such stem cells and progenitor cells. Although the molecular biology underlying NSC migration is far from clear, molecules like nuclear factor kappa B (NF- $\kappa \mathrm{B}$ ), macrophage chemoattractant protein-1, stem cell factor, stromal cell-derived factor-1 (SDF-1), and platelet derived growth factor were demonstrated to play an important role in the regulation of this process (reviewed in [194]). For most of these factors, however, the role in glioma cell migration is not yet known.

For a more systematic discussion of the mechanisms and factors that are relevant for diffuse infiltration of glioma cells in the neuropil, a comparison with guerilla warriors may be helpful again. One would not only like to know what exactly initiates the migratory behavior of such warriors, but also which qualities and environmental factors enable them to successfully perform this behavior. With regard to these latter aspects, one could recognize (a) an internal system that coordinates input and output of signals, (b) a locomotor apparatus, (c) trails to travel on, (d) parts that directly interact with these trails, (e) tools to remove obstacles, (f) microenvironmental signals that guide the way, and (g) other stimulatory or permissive microenvironmental factors (Fig. 3). Before discussing these aspects in more detail it is important to realize that (the interactions of) these underlying mechanisms are complex, that the list of factors associated with glioma cell invasion/migration given below is not complete, and that information about the exact role of these factors is often obtained in glioma models that do not exactly mimic diffuse infiltration of glioma cells in the neuropil.

Intracellular integration of signals

Interactions of glioma cells with their microenvironment via membrane receptors (integrins, growth factor receptors) induces intracellular signals which are transmitted through effectors like the focal adhesion kinase (FAK) family of cytoplasmic, non-receptor tyrosine kinases and P311. The FAK family consists of two proteins, FAK and pyruvate kinase (Pyk) 2, which both play an important role in intracellular events such as proliferation, migration, survival, and apoptosis [117]. Glioma cells were reported to show increased expression of FAK, esp. at the invasive front [201]. FAK is activated by phosphorylation on critical tyrosine residues [161] and subsequently it phosphorylates cytoskeleton-associated substrates (e.g., Src, paxillin) [99]. While some studies suggest a role for FAK activation mainly in glioma cell proliferation [101], other studies show involvement in activation of Rac, which in turn leads to actin polymerization and formation of cell protrusions, focal adhesion, and subsequent motility [24, 142]. Pyk2 has a similar sequence and structure as FAK and can, upon activation by phosphorylation, interact with many of the same intracellular proteins as FAK [101]. P311 is a small polypeptide that was identified as migration-associated by 


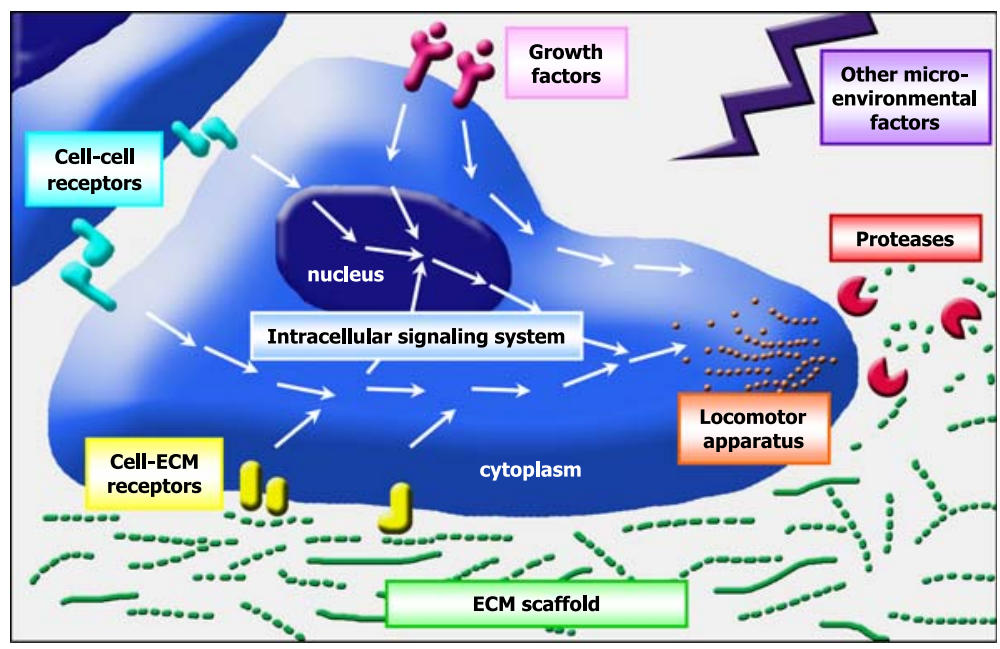

Fig. 3 Schematic overview of factors and mechanisms important for diffuse infiltration of glioma cells in the neuropil. As discussed in the section on the molecular background of diffuse infiltrative glioma growth, the following aspects relevant for this growth pattern can be recognized: (a) an intracellular system that coordinates all incoming and outgoing signals via a complex set of pathways, (b) a locomotor apparatus in which the actin cytoskeleton plays a crucial role, (c) a scaffold (ECM, surface of cells/cell processes) on which the glioma

comparing invasive human GBM cells with cells from the tumor core. The overexpressed P311 localizes to focal adhesions and promotes glioma cell migration via Rac1 activation [109, 113]. Transcription factors like FoxM1B and NF- $\kappa \mathrm{B}$ also contribute to intracellular integration of signals $[37,103,148]$. FoxM1B was shown to be overexpressed in human GBMs, while in vitro and in vivo experiments revealed that this factor enhances glioma invasion by stimulation of matrix metalloproteinase 2 (MMP-2) transcription $[37,103]$. The NF- $\kappa \mathrm{B}$ level is elevated in actively migrating glioma cells in vitro and in vivo where it plays an important role in cell survival [148].

Actin cytoskeleton rearrangements

Cell migration requires dynamic remodeling of the actin cytoskeleton through assembly, disassembly, and organization of actin filaments into functional networks, which direct protrusion at the front of the cell and retraction at the rear. One of the first steps in cell migration is the formation of actin-rich structures, termed lamellipodia, at the leading edge of the motile cell [142]. These lamellipodia are broad, sheet-like protrusions containing short-branched actin filaments [133]. In addition to lamellipodia, more slender cytoplasmic protrusions containing bundels of cross-linked actin filaments (filopodia) can be formed [142]. Members of the Rho family of small GTP binding proteins, esp. Rac and cell division cycle protein $\mathrm{Cdc} 42$, are pivotal regulators of these processes. When bound to GTP, these proteins can interact with downstream target proteins, including protein cells can travel, (d) cell-ECM and/or cell-cell receptors that allow direct interaction with the ECM and cellular microenvironment, (e) tools to remove obstacles like ECM degrading proteases, (f) growth factors that guide the way, and ( $\mathrm{g}$ ) other stimulatory or permissive microenvironmental factors (e.g., chemokines derived from inflammatory cells). In this scheme, the protrusion on the right side of the cell represents the lamellipodium at the front

kinases, phosphatases, and WASP/WAVE proteins (Wiskott-Aldrich Syndrome protein/Wiskott-Aldrich Syndrome protein family members). These latter proteins are activators of the Actin-related protein Arp2/3 complex, a nucleator of new actin filaments at the leading edge of the cell and thereby instrumental for protrusion of lamellipodia and filopodia $[47,124,142]$. Several studies showed that inhibition of Rac1, one of the three Rac isoforms, inhibits glioma cell migration and invasion in vitro [32, 34]. Depletion of the phosphoinositide phosphatase synaptojanin-2 (another effector of Rac1) using small interfering RNA was reported to inhibit glioma cell invasion through Matrigel and rat brain slices in vitro [34]. Interestingly, Rac is one of the downstream targets of phosphatidylinositol 3-kinase (PI3K), and the effect of PI3K [i.e., phosphorylation of PI4,5-bisphosphate (PIP2)] is counteracted by the tumor suppressor protein phosphatase and tensin homolog (PTEN) [29]. By dephosphorylating PIP3, PTEN may inhibit glioma cell invasion in two ways: by modulation of glioma cell motility by inactivating Rac and $\mathrm{Cdc} 42$ as well as by suppression of extracellular matrix (ECM) degradation via MMPs [53]. As loss of chromosome 10q, which contains the PTEN gene (locus: 10q23.3), is a frequent event in esp. GBMs [42, 67], such loss may thus result in increased migration.

\section{Scaffold for migration}

In normal brain, common ECM components such as collagens, laminin, and fibronectin are essentially restricted to 
the vessel walls and the perivascular and subpial glial limiting membrane [60]. The exact composition of the ECM in the neuropil is not yet fully elucidated, but hyaluronan, glycosaminoglycans, and proteoglycans are considered to be major ECM components in this compartment [13, 60, 63]. Due to the dense network of cell processes the volume of the extracellular space in the normal neuropil is limited. In diffuse gliomas, this space increases in volume, becomes more irregular, and abnormal ECM components accumulate in this space [204]. The fact that, in contrast to almost all other tumors, glioma cells have the capacity to diffusely infiltrate in the neuropil suggests that unique cell-ECM or cell-cell interactions are involved [179]. Glioma cells may create their own microenvironment by synthesizing and depositing ECM molecules such as vitronectin, tenascin-C, and laminin [21, 74, 84, 112, 128, 153, 180, 202, 204]. The glycoprotein vitronectin is preferentially expressed at the advancing margins of gliomas, and its expression level was described to correlate with glioma grade [180]. Additionally, vitronectin was reported to confer a survival advantage for tumor cells at the advancing tumor margin [180]. Increased expression of tenascin- $\mathrm{C}$ was described to correlate with higher malignancy grade [74] as well as to promote endothelial cell adhesion, spreading, and migration, which are critical steps in the process of angiogenesis [202]. Laminin deposits were found in the border zone between the normal brain and the migrating glioma cells in an orthotopic glioma animal model [112, 128]. Also in vitro, glioma cells express and secrete laminin. It was suggested that laminin production by glioma cells is stimulated by growth factors and gangliosides [84]. Other ECM components that show an increased expression in gliomas include osteopontin, secreted protein acidic and rich in cystein (SPARC), thrombospondin, and brain enriched hyaluronic acid binding protein [13]. Apart from ECM components, glioma cells may also use the surface of neighboring neuronal and glial cells (including myelin sheaths) as a scaffold for diffuse infiltration in the neuropil. Interestingly, myelin was reported to be one of the most permissive substrates for attachment and migration of glioma cells [58]. This phenomenon may at least partly explain the histopathological finding that glioma cells preferentially migrate in white matter tracts.

\section{Cell-ECM and cell-cell interactions}

Glioma cell migration requires dynamic expression of adhesion molecules, adequate positioning of these molecules, attachment to a relevant substrate, and detachment when the cell moves on. CD44 and integrins are considered to play a major role in glioma cell-ECM adhesion. CD44 is a hyaluronan receptor with a high expression in gliomas that was described to correlate with glioma grade [4, 13].
Engagement of CD44 with its ligand activates the small GTP binding protein Rac1, leading to actin cytoskeleton rearrangements and redistribution of CD44 to membrane ruffles. Proteolytic cleavage of CD44 by a disintegrin and metalloproteinase 10 produces an intramembranous cleavage product which acts as signal transduction molecule that in turn enhances invasion of glioma cells [120]. Integrins are a family of calcium-dependent, transmembrane molecules that mediate cell-ECM and cell-cell adhesion and consist of a non-covalently linked $\alpha$ and $\beta$ subunit. ECM binding integrins bind esp. to the RGD sequence in the ECM components. Through the cytoplasmic domain of the $\beta$ subunit, integrin activation can lead to activation of FAK, and of its intracellular signal transduction pathway [77, 142]. Subsequently, cytoskeletal rearrangements may occur and lead to cell movement [52]. Integrins that were described to be upregulated on glioma cells are $\alpha 3 \beta 1, \alpha \mathrm{v} \beta 1$, $\alpha \mathrm{v} \beta 3, \alpha \mathrm{v} \beta 5$, the two latter integrins being receptors for vitronectin. In addition, $\alpha \mathrm{v} \beta 3$ can also bind to laminin, fibronectin, and tenascin-C [97]. The poliovirus receptor CD155/PVR, which is recruited to the leading edge of migrating cells where it co-localizes with actin and $\alpha \mathrm{v}$ integrins and binds to vitronectin, was shown to be highly expressed in GBMs [94]. Expression of this adhesion molecule leads to increased FAK signaling and adhesioninduced activation of paxillin. Forced expression of CD155 in glioma cells resulted in increased dispersal of these cells in mice brains, while knock down of this receptor caused a decrease in migration of U87 cells in vitro [164, 165]. Other examples of adhesion molecules with a changed expression pattern in gliomas include adhesion molecule on glia/ $\beta 2$ subunit of $\mathrm{Na}, \mathrm{K}-\mathrm{ATPase}$ (AMOG/ $\beta 2$ ), ephrin receptor tyrosine kinases (EphB2-B3), fibroblast growth factor inducible 14 receptor (Fn14), and protein tyrosine phosphatases zeta/ beta $[50,121,122,158,178]$. For cell-cell interactions in glioma migration cadherins and neural cell adhesion molecules (NCAM) may be important. Cadherins are calciumdependent transmembrane cell-cell adhesion glycoproteins that form adherens junctions by homophilic interactions. Intracellularly, they link to the actin cytoskeleton via catenins (p120 catenin) [79]. Instability and disorganization of cadherin-mediated junctions lead to increased migration and invasiveness of glioma cells in vitro [5]. NCAM is a member of the glycoprotein immunoglobulin receptor superfamily and mediates strong interactions between cells via homophilic binding. The finding that expression of NCAM is inversely correlated with glioma grade suggests that loss of this adhesion molecule allows tumor cells to detach from neighboring (tumor and/or non-neoplastic) cells and to migrate into the brain parenchyma $[125,155]$. Increased invasion of polysialylated C6 rat glioma cells into the murine corpus callosum may be explained by attenuation of homophilic NCAM interactions [174]. 


\section{Proteases}

In analogy with invasion of other cancer cells it is often hypothesized that glioma cells remodel their microenvironment by degrading the surrounding ECM to render it permissive for migration. Based on in vitro studies, several glioma derived proteolytic enzymes involved in cell migration were discovered, such as Cathepsin B; MMP-2 (synonym: Gelatinase A); MMP-9 (Gelatinase B); MMP-12; urokinase-type plasminogen activator (uPA) [20, 64, 137, 153, 193, 198]. These proteases are synthesized and secreted as inactive pro-enzymes and activated by proteolytic cleavage outside the cell. For some of these proteases a role in glioma invasion has been confirmed in in vivo studies [64, 90, 156], their expression being correlated with glioma grade and infiltrative capacity. The expression of these proteases is tightly regulated and can, for example, be activated by interaction of the glioma cell with the surrounding ECM. Several studies showed that the activation of ERK and Akt pathways stimulates secretion of MMP-2 and -9 [81, 187]. In an in vitro study, tenascin-C was reported to increase invasiveness of glioma cells through up-regulation of MMP-12 [153]. Overexpression of SPARC by glioma cells was described to cause increased expression of uPA, uPAR, MMP-2 and -9, which then leads to upregulation of PI3K and RhoA [85].

\section{Growth factors and related signaling molecules}

While in vitro studies revealed that Epidermal Growth Factor (EGF), basic Fibroblast Growth Factor (bFGF), and Transforming Growth Factor $\beta$ significantly affect invasion of glioma cells (for review see [33]), many questions remain about the origin (tumor cells? inflammatory cells? pre-existent brain cells?) and exact role of such growth factors in vivo. Esp. GBM cells often show mutation or amplification of the EGF receptor gene and overexpression of this receptor on the cell surface [105, 123]. Other studies indicate that Scatter Factor/Hepatocyte Growth Factor (HGF) is important for glioma cell migration. HGF binds to the tyrosine kinase c-Met receptor, and both HGF and its receptor are frequently overexpressed in gliomas. HGFbinding to c-Met results in autophosphorylation of the receptor, subsequent activation of several signaling pathways (e.g., MAPK-, Jak/Stat-, PI3K-pathways), and various cellular reactions including migration [66]. Recently, it was shown that hypoxia-induced HIF- $1 \alpha$ causes up-regulation of c-Met and thereby enhances the effect of HGF on glioma migration [44]. Insulin-like Growth Factor (IGF) binds with high affinity with IGF-Binding Protein 2 (IGFBP2), a soluble protein that is frequently overexpressed in high-grade gliomas. Overexpression of IGFBP2 results in upregulation of invasion related genes such as
MMP-2 [186]. The Invasion Inhibitory Protein (IIp45) inhibits glioma invasion in vitro as well as in vivo in an orthotopic xenograft model by binding to IGFBP2 [168]. Iip45 was reported to be underexpressed in GBMs due to inactivation by tumor-specific alternative splicing [169]. The expression of the cell surface chemokine receptor CXCR4 is much higher in invasive than in non-invasive glioma cells [45]. Binding of its ligand, SDF-1/CXCL12, leads to activation of Akt and ERK1/2 signaling pathways and, subsequently, to increased survival, proliferation, and (via activation of proMMP-2) to increased invasion [145, 195]. Expression of the angiogenic factor angiopoetin-2 (Ang2) was found to be high in esp. the invasive areas of gliomas and to induce upregulation of MMP-2 in vivo and in vitro $[68,76,83,90]$.

\section{Inflammatory cells and other factors}

While high-grade malignant gliomas were described to contain large numbers of microglial cells and macrophages, lower numbers of microglial cells were found in low-grade diffuse gliomas [143]. These cells are able to produce cytokines and growth factors and may contribute to evasion of immune attack as well as stimulate tumor growth, but the exact effect of such inflammatory cells in gliomas is not known [188]. The findings that glioma patients show an increased number of immune-suppressive regulatory $\mathrm{T}$ cells (not only in the tumor tissue, but also in peripheral blood) and that expression of MHC class I and II molecules is downregulated on invading glioma cells may explain that diffuse infiltrative glioma cells can evade an immuneresponse (a phenomenon that has been called "stealth invasion of the brain") $[46,202]$.

\section{Therapy}

Like for guerilla warriors, conventional methods to fight diffuse infiltrative glioma cells have limited effect or cause too much collateral damage, and a "search \& destroy" tactic may be needed.

\section{Conventional therapies}

The fact that diffuse infiltrative glioma cells tend to blend in extensively in the brain microenvironment makes it hard to plan an effective counterattack. Whereas surgery of most other tumors aims at complete resection (with or without a margin of normal tissue), the diffuse growth of gliomas in the brain parenchyma precludes complete tumor removal. Already in the early days of neurosurgery, Dandy and Gardner noticed that even after performing a hemispherectomy glioma patients were not necessarily cured $[38,56]$. 
Still, for patients with a high-grade malignant glioma maximal removal of the contrast-enhancing tissue without worsening neurological impairment is an independent prognostic factor for overall survival [73, 140]. Intraoperative assessment of the extent of resection by the neurosurgeon is, however, inaccurate [2, 170]. Also, although radiotherapy was proven to be beneficial for malignant glioma patients, eradicating diffuse infiltrative glioma cells by radiotherapy without significantly damaging the infiltrated brain parenchyma has been difficult to achieve [80, 93, 95]. Up till now limited field irradiation (generally with an arbitrary $2 \mathrm{~cm}$ beyond the contrast enhancing mass) rather than whole brain irradiation is the standard treatment [95]. The success of chemotherapy is hampered by the marked intratumoral heterogeneity of gliomas [140]. Esp. in areas where the original tissue architecture is relatively preserved, the blood-brain barrier may form an obstacle for optimal delivery of chemotherapeutics to diffuse infiltrative tumor cells. Patients with malignant oligodendroglial tumors [esp. those with loss of the short arm of chromosome 1 and of the long arm of chromosome 19 (-1p/-19q)] often show response to chemotherapy using alkylating agents [28, 182]. Recently, temozolomide treatment (concomitant and adjuvant with radiotherapy) was shown to result in modest improvement of median overall survival and increased 2 years survival in GBM patients up to 70 years of age [171]. However, up till now diffuse glioma patients are far from being cured by conventional therapies, and there is an urgent need for other therapeutic approaches [140].

"Anti-invasive" therapies

Interference with glioma cell motility may be exploited as a novel therapeutic approach [59]. We will now discuss some examples of experimental studies interfering with different aspects of glioma cell migration. Inhibition of FAK activation by TAE226 not only led to reduction of glioma cell adhesion, migration, and invasion through an artificial ECM, but also to reduced proliferation and enhanced apoptosis of these cells [161]. In an in vitro study, the Ras inhibitor S-trans, trans-farnesyl thiosalicylic acid was reported to reduce migration and anchorage-dependent proliferation of GBM cells by inhibiting PI3K signaling and Rac1 activity [62]. Application of the $\alpha v \beta 5$ integrin antagonist SJ749 not only reduced adhesion of glioma cells to fibronectin but also proliferation of these cells in vitro [107], while the $\alpha \mathrm{v} \beta 3$ inhibitor IS20I exhibited strong anti-mitotic and antimigratory effects in vitro and reduced glioma growth in vivo in subcutaneous and intracerebral glioma models [15]. In a recent phase I trial including 51 malignant glioma patients that were treated with the $\alpha \mathrm{v}$ integrin inhibitor EMD 121974 (cyclo Arg-Gly-Asp-D-Phe-(N-methyl)-Val, a cyclic RGD pentapeptide) complete response was seen in two patients and partial response in three patients [196]. In preclinical trials using orthotopic U87 glioma lesions in nude mice, this inhibitor was described to induce anoikis (apoptosis supposedly induced by detachment from the ECM) in angiogenic blood vessels and brain tumor cells [175]

Application of the anti-tenascin antibody $81 \mathrm{C} 6$ has been studied in a phase II clinical trial. Injection of ${ }^{131} \mathrm{I}-\mathrm{m} 81 \mathrm{C6}$ (44 Gy) in the surgically created resection cavity of patients with recurrent malignant glioma followed by standardized chemotherapy resulted in prolonged median survival [139]. Downregulation of SPARC in glioma cells using short interfering RNA decreased tumor cell survival and invasion in vitro by reducing phosphorylation of AKT, FAK, and integrin-linked kinase [160]. Downregulation of uPA, UPAR, and MMP-9 by RNA interference was reported to result in decreased invasion in both Matrigel and spheroidassays in vitro, and in regression of orthotopic gliomas in nude mice [64]. The synthetic MMP inhibitors batimastat and marimastat reduced glioma invasion in vitro [177]. Local treatment of intracerebral glioma models in mice with an anti-c-Met antibody (OA-5D5) resulted in major growth inhibition of U87 lesions, but not of G55 lesions. As G55 tumors express c-Met but lack HGF expression, only gliomas where HGF drives tumor growth may thus respond to anti-c-Met-therapy [110]. EGFR, which is frequently overexpressed in GBMs, can be targeted with EGFR kinase inhibitors like gefitinib and erlotinib. Only a small number of the GBM patients that were treated with such inhibitors showed response (esp. those in which the glioma cells coexpressed EGFRvIII and PTEN) [115].

The tyrosine kinase inhibitors emodin and aloe emodin have been shown to induce anti-cancer effects in various tumor types. Emodin was reported to inhibit secretion of MMP-2 and - 9 by glioma cells, invasion through a Matrigel coated chamber, phosphorylation of FAK, ERK1/2 and $\mathrm{Akt} / \mathrm{PKB}$, and inhibition of glioma invasion in vitro and in vivo [81, 116]. PEX, a fragment of MMP-2, is an endogenous inhibitor of angiogenesis, cell proliferation, and migration. The expression level in gliomas was described to be correlated with glioma grade and with expression of $\alpha \mathrm{v} \beta 3$ integrin to which it is bound. One study showed that, while endogenous PEX expression was not sufficient to inhibit glioma growth, administration of PEX inhibited cell migration in vitro as well as angiogenesis and glioma cell proliferation in subcutaneous and intracranial human glioma xenografts [14].

\section{Other therapeutic approaches}

Driven by the failure of conventional therapeutic approaches for diffuse glioma patients, several other therapeutic strategies for these tumors are being developed or 
already introduced in the clinic. Because of the striking microvascular changes in high-grade gliomas, these tumors have since long been considered as good candidates for anti-angiogenic therapy [51]. However, as in diffuse gliomas many intratumoral vessels may be incorporated rather than newly formed, the actual effect of anti-angiogenic therapy remains to be seen. Anti-VEGF therapy in experimental orthotopic GBM models resulted not only in reduction of vascular changes but also in increased vessel co-option by the tumor $[86,92]$.

Unravelling the stem cell aspects of gliomas may provide new targets for therapy [185]. Furthermore, as nonneoplastic NSCs were shown to be able to migrate toward and induce apoptosis of glioma cells, such stem cells may be used as vehicles to target infiltrating glioma cells ("search \& destroy") [108, 197]. Further research now concentrates on how to optimally arm stem cells for this purpose. In orthotopic glioma models injection of NSCs transduced with the gene for cytosine deaminase led to a strong reduction of tumor burden [1]. Similarly, a promising result was obtained in a study in which orthotopic C6 rat glioma models were injected with NSCs transduced with herpes simplex virus-thymidine kinase gene (NSCtk) followed by systemic ganciclovir administration. The NSCs were shown to migrate actively from injection sites toward the C6 tumor cells in both the ipsi- and contralateral hemisphere and caused marked inhibition of tumor growth and increased survival [100].

With convection-enhanced delivery (CED), one or more small-caliber catheters are placed through a burr hole into the target tissue under image guidance, and an infusate is actively pumped into the brain parenchyma. This infusate will then disperse through the interstitial space [136, 150, 183]. Using CED, different therapeutics (e.g., chemotherapeutics, endotoxins, radioisotopes, chimeric products) may reach diffuse infiltrative glioma cells in the brain parenchyma [118, 119]. Although the pre-clinical results are promising $[87,126,190]$, it is clear that the positioning of the catheter is crucial for the success of this approach, and that the distribution of the infusate should be closely monitored during treatment [151].

Glioma patients can be vaccinated with dendritic cells that are loaded with tumor-associated peptides. Ideally such dendritic cells then stimulate a cytotoxic T-cell response against the tumor. In gliomas, this approach is hampered by the large inter- and intratumoral antigenic heterogeneity and the lack of a universally expressed tumor antigen. Alternatively, dendritic cells can be loaded with a cell lysate derived from the patient's own glioma. Using this latter method, an overall prolonged median survival was found [39]. As an increased number of immune-suppressive, regulatory T cells was found in GBMs [46], interference with such cells also represents a potential target for immunotherapy of malignant gliomas [65]. Several studies investigated the potential of oncolytic viruses as vectors for gene therapy in the treatment of gliomas. Up till now, the success of virotherapy is limited, partly because of the host immune response which attenuates the distribution of the viruses and is difficult to control. Furthermore, as diffuse infiltrative glioma cells may show limited proliferative activity, and virus replication occurs preferentially in proliferating cells, the effect of virotherapy on the diffuse infiltrative part of gliomas remains to be elucidated [48, 159, 167].

\section{Concluding remarks and future perspectives}

The unique diffuse infiltrative growth of gliomas in the brain parenchyma has important diagnostic, prognostic, and therapeutic implications. While the understanding of different aspects of this growth pattern may be facilitated by using guerilla war as a metaphor, the analogy is of course not perfect. For instance, up till now it is unclear if and how the brain tissue "fights back". Furthermore, it is important to realize that the diffuse infiltrative growth pattern is not just the result of malignant progression as both low- and high-grade diffuse gliomas display this phenomenon. Esp. the high-grade lesions frequently show marked phenotypical heterogeneity with spatial differences in cellular phenotype and malignancy grade. Therefore, in a clinical setting combination of clinical, radiological, and pathological information is warranted to avoid diagnostic inaccuracy, particularly in cases where only small biopsy specimens are available for histopathological diagnosis.

Unravelling the mechanisms that allow glioma cells to diffusely infiltrate in the neuropil may provide novel therapeutic targets for recognizing, attacking, and killing these cells. Investigations using glioma models have already provided a wealth of information on the biological mechanisms responsible for glioma cell migration. However, many of these experiments were performed in in vitro and in vivo models that poorly recapitulate the glio ma cellmicroenvironment interactions of human glioma cells in brain tissue [153]. Moreover, the exact culture conditions may have a major influence on the results obtained. For example, it was shown that cultured glioma cells may show a "mesenchymal drift" due to transdifferentiation [127], and that GBM cells cultured in vitro with FGF and EGF more closely mirror the phenotype and genotype of the original tumors than GBM cells cultured in serum [98].

Even the results obtained in orthotopic animal models for gliomas should be interpreted with caution, as such models not always mimic the genotype and/or phenotype of the original human gliomas. In fact such models often show a compact, expansive rather than diffuse infiltrative growth 
pattern in the brain $[86,196]$. Furthermore, it is important to realize that different mechanisms may underlie perivascular growth versus diffuse infiltrative growth of glioma cells in the neuropil, e.g., because conventional ECM components are absent in the latter compartment [146].

As has been suggested before [25], diffuse gliomas are unlikely to be cured by techniques that cannot selectively destroy the neoplastic cells. While interference with the mechanisms underlying diffuse glioma growth may be exploited as a novel therapeutic approach, up till now the crucial prerequisites for this growth pattern are far from clarified. Ideally, studies aiming at further elucidation of these mechanisms should be performed in original human glioma tissue and in (orthotopic) models that genotypically and phenotypically closely mimic the situation in human glioma patients [147, 154]. It is to be expected that esp. such studies will ultimately disclose the Achilles heel of the diffuse infiltrative glioma cells.

Acknowledgments We would like to thank Dr Mathé Prick, Department of Neurology, Canisius Wilhelmina Hospital, Nijmegen, The Netherlands for providing the images of patients illustrating radiological aspects of glioma growth, and Sandra Boots-Sprenger, Department of Neurology and Radiology, RUNMC, for her excellent support in creating Figs. 1 and 3. AC and PW are supported by Dutch Cancer Society grant KUN 2003-2975. AJI is supported by EU the 6th framework grant LSH-2002-2.2.0-5 (eTUMOUR).

\section{References}

1. Aboody KS, Brown A, Rainov NG, Bower KA, Liu S, Yang W, Small JE, Herrlinger U, Ourednik V, Black PM, Breakefield XO, Snyder EY (2000) Neural stem cells display extensive tropism for pathology in adult brain: evidence from intracranial gliomas. Proc Natl Acad Sci USA 97:12846-12851

2. Albert FK, Forsting M, Sartor K, Adams HP, Kunze S (1994) Early postoperative magnetic resonance imaging after resection of malignant glioma: objective evaluation of residual tumor and its influence on regrowth and prognosis. Neurosurgery 34:45-60

3. Aronen HJ, Pardo FS, Kennedy DN, Belliveau JW, Packard SD, Hsu DW, Hochberg FH, Fischman AJ, Rosen BR (2000) High microvascular blood volume is associated with high glucose uptake and tumor angiogenesis in human gliomas. Clin Cancer Res 6:2189-2200

4. Aruffo A, Stamenkovic I, Melnick M, Underhill CB, Seed B (1990) CD44 is the principal cell surface receptor for hyaluronate. Cell 61:1303-1313

5. Asano K, Duntsch CD, Zhou Q, Weimar JD, Bordelon D, Robertson JH, Pourmotabbed T (2004) Correlation of N-cadherin expression in high grade gliomas with tissue invasion. J Neurooncol 70:3-15

6. Bao S, Wu Q, McLendon RE, Hao Y, Shi Q, Hjelmeland AB, Dewhirst MW, Bigner DD, Rich JN (2006) Glioma stem cells promote radioresistance by preferential activation of the DNA damage response. Nature 444:756-760

7. Bao S, Wu Q, Sathornsumetee S, Hao Y, Li Z, Hjelmeland AB, Shi Q, McLendon RE, Bigner DD, Rich JN (2006) Stem cell-like glioma cells promote tumor angiogenesis through vascular endothelial growth factor. Cancer Res 66:7843-7848
8. Barker FG, Chang SM, Huhn SL, Davis RL, Gutin PH, McDermott MW, Wilson CB, Prados MD (1997) Age and the risk of anaplasia in magnetic resonance-nonenhancing supratentorial cerebral tumors. Cancer 80:936-941

9. Barker PB, Lin DD (2006) In vivo proton MR spectroscopy of the human brain. Prog Nucl Mag Res Sp 49:99-128

10. Barnard RO, Geddes JF (1987) The incidence of multifocal cerebral gliomas. A histologic study of large hemisphere sections. Cancer 60:1519-1531

11. Batzdorf U, Malamud N (1963) The problem of multicentric gliomas. J Neurosurg 20:122-136

12. Baumert BG, Rutten I, Dehing-Oberije C, Twijnstra A, Dirx MJ, Debougnoux-Huppertz RM, Lambin P, Kubat B (2006) A pathology-based substrate for target definition in radiosurgery of brain metastases. Int J Radiat Oncol Biol Phys 66:187-194

13. Bellail AC, Hunter SB, Brat DJ, Tan C, Van Meir EG (2004) Microregional extracellular matrix heterogeneity in brain modulates glioma cell invasion. Int J Biochem Cell Biol 36:1046-1069

14. Bello L, Lucini V, Carrabba G, Giussani C, Machluf M, Pluderi M, Nikas D, Zhang J, Tomei G, Villani RM, Carroll RS, Bikfalvi A, Black PM (2001) Simultaneous inhibition of glioma angiogenesis, cell proliferation, and invasion by a naturally occurring fragment of human metalloproteinase-2. Cancer Res 61:8730-8736

15. Bello L, Lucini V, Giussani C, Carrabba G, Pluderi M, Scaglione F, Tomei G, Villani R, Black PM, Bikfalvi A, Carroll RS (2003) IS20I, a specific alphavbeta3 integrin inhibitor, reduces glioma growth in vivo. Neurosurgery 52:177-185

16. Benard F, Romsa J, Hustinx R (2003) Imaging gliomas with positron emission tomography and single-photon emission computed tomography. Semin Nucl Med 33:148-162

17. Berkman RA, Clark WC, Saxena A, Robertson JT, Oldfield EH, Ali IU (1992) Clonal composition of glioblastoma multiforme. J Neurosurg 77:432-437

18. Bernas LM, Foster PJ, Rutt BK (2007) Magnetic resonance imaging of in vitro glioma cell invasion. J Neurosurg 106:306-313

19. Bernsen H, van der Laak J, Kusters B, Van der Ven A, Wesseling P (2005) Gliomatosis cerebri: quantitative proof of vessel recruitment by cooptation instead of angiogenesis. J Neurosurg 103:702-706

20. Bettinger I, Thanos S, Paulus W (2002) Microglia promote glioma migration. Acta Neuropathol (Berl) 103:351-355

21. Brack SS, Silacci M, Birchler M, Neri D (2006) Tumor-targeting properties of novel antibodies specific to the large isoform of tenascin-C. Clin Cancer Res 12:3200-3208

22. Brat DJ, Van Meir EG (2001) Glomeruloid microvascular proliferation orchestrated by VPF/VEGF: a new world of angiogenesis research. Am J Pathol 158:789-796

23. Brat DJ, Castellano-Sanchez AA, Hunter SB, Pecot M, Cohen C, Hammond EH, Devi SN, Kaur B, Van Meir EG (2004) Pseudopalisades in glioblastoma are hypoxic, express extracellular matrix proteases, and are formed by an actively migrating cell population. Cancer Res 64:920-927

24. Brown MC, Cary LA, Jamieson JS, Cooper JA, Turner CE (2005) Src and FAK kinases cooperate to phosphorylate paxillin kinase linker, stimulate its focal adhesion localization, and regulate cell spreading and protrusiveness. Mol Biol Cell 16:4316-4328

25. Burger PC (1987) The anatomy of astrocytomas. Mayo Clin Proc 62:527-529

26. Burger PC, Kleihues P (1989) Cytologic composition of the untreated glioblastoma with implications for evaluation of needle biopsies. Cancer 63:2014-2023

27. Burger PC, Heinz ER, Shibata T, Kleihues P (1988) Topographic anatomy and CT correlations in the untreated glioblastoma multiforme. J Neurosurg 68:698-704

28. Cairncross G, Berkey B, Shaw E, Jenkins R, Scheithauer B, Brachman D, Buckner J, Fink K, Souhami L, Laperierre N, Mehta M, Curran W (2006) Phase III trial of chemotherapy plus 
radiotherapy compared with radiotherapy alone for pure and mixed anaplastic oligodendroglioma: intergroup radiation therapy oncology group trial 9402. J Clin Oncol 24:2707-2714

29. Cantley LC (2002) The phosphoinositide 3-kinase pathway. Science 296:1655-1657

30. Cao Y, Sundgren PC, Tsien CI, Chenevert TT, Junck L (2006) Physiologic and metabolic magnetic resonance imaging in gliomas. J Clin Oncol 24:1228-1235

31. CBTRUS (2006) CBTRUS statistical report. Primary brain tumors in the United States, 1998-2002. Central Brain Tumor Registry of the United States. http://www.cbtrus.org

32. Chan AY, Coniglio SJ, Chuang YY, Michaelson D, Knaus UG, Philips MR, Symons M (2005) Roles of the Rac1 and Rac3 GTPases in human tumor cell invasion. Oncogene 24:7821-7829

33. Chicoine MR, Silbergeld DL (1997) Mitogens as motogens. J Neurooncol 35:249-257

34. Chuang YY, Tran NL, Rusk N, Nakada M, Berens ME, Symons M (2004) Role of synaptojanin 2 in glioma cell migration and invasion. Cancer Res 64:8271-8275

35. Croteau D, Scarpace L, Hearshen D, Gutierrez J, Fisher JL, Rock JP, Mikkelsen T (2001) Correlation between magnetic resonance spectroscopy imaging and image-guided biopsies: semiquantitative and qualitative histopathological analyses of patients with untreated glioma. Neurosurgery 49:823-829

36. Cummings TJ, Hulette CM, Longee DC, Bottom KS, McLendon RE, Chu CT (1999) Gliomatosis cerebri: cytologic and autopsy findings in a case involving the entire neuraxis. Clin Neuropathol 18:190-197

37. Dai B, Kang SH, Gong W, Liu M, Aldape KD, Sawaya R, Huang $S$ (2007) Aberrant FoxM1B expression increases matrix metalloproteinase-2 transcription and enhances the invasion of glioma cells. Oncogene. doi:10.1038/sj.onc. 1210443

38. Dandy WE (1928) Removal of the right hemisphere for certain tumors with hemiplegia: preliminary report. J Am Med Assoc 90:823-825

39. De Vleeschouwer S, Rapp M, Sorg RV, Steiger HJ, Stummer W, van Gool S, Sabel M (2006) Dendritic cell vaccination in patients with malignant gliomas: current status and future directions. Neurosurgery 59:988-999

40. Demuth T, Berens ME (2004) Molecular mechanisms of glioma cell migration and invasion. J Neurooncol 70:217-228

41. Di Costanzo A, Scarabino T, Trojsi F, Giannatempo GM, Popolizio T, Catapano D, Bonavita S, Maggialetti N, Tosetti M, Salvolini U, d'Angelo VA, Tedeschi G (2006) Multiparametric 3T MR approach to the assessment of cerebral gliomas: tumor extent and malignancy. Neuroradiology 48:622-631

42. Duerr EM, Rollbrocker B, Hayashi Y, Peters N, Meyer-Puttlitz B, Louis DN, Schramm J, Wiestler OD, Parsons R, Eng C, von DA (1998) PTEN mutations in gliomas and glioneuronal tumors. Oncogene 16:2259-2264

43. Earnest F, Kelly PJ, Scheithauer BW, Kall BA, Cascino TL, Ehman RL, Forbes GS, Axley PL (1988) Cerebral astrocytomas: histopathologic correlation of MR and CT contrast enhancement with stereotactic biopsy. Radiology 166:823-827

44. Eckerich C, Zapf S, Fillbrandt R, Loges S, Westphal M, Lamszus K (2007) Hypoxia can induce c-Met expression in glioma cells and enhance SF/HGF-induced cell migration. Int J Cancer 121:276-283

45. Ehtesham M, Winston JA, Kabos P, Thompson RC (2006) CXCR4 expression mediates glioma cell invasiveness. Oncogene 25:2801-2806

46. El Andaloussi A, Lesniak MS (2006) An increase in $\mathrm{CD} 4+\mathrm{CD} 25+\mathrm{FOXP} 3+$ regulatory $\mathrm{T}$ cells in tumor-infiltrating lymphocytes of human glioblastoma multiforme. Neuro Oncol 8:234-243

47. Etienne-Manneville S, Hall A (2002) Rho GTPases in cell biology. Nature 420:629-635
48. Everson RG, Gromeier M, Sampson JH (2007) Viruses in the treatment of malignant glioma. Expert Rev Neurother 7:321-324

49. Fischer I, Gagner JP, Law M, Newcomb EW, Zagzag D (2005) Angiogenesis in gliomas: biology and molecular pathophysiology. Brain Pathol 15:297-310

50. Foehr ED, Lorente G, Kuo J, Ram R, Nikolich K, Urfer R (2006) Targeting of the receptor protein tyrosine phosphatase beta with a monoclonal antibody delays tumor growth in a glioblastoma model. Cancer Res 66:2271-2278

51. Folkman J (1972) Anti-angiogenesis: new concept for therapy of solid tumors. Ann Surg 175:409-416

52. Fukushima Y, Ohnishi T, Arita N, Hayakawa T, Sekiguchi K (1998) Integrin alpha3beta1-mediated interaction with laminin-5 stimulates adhesion, migration and invasion of malignant glioma cells. Int J Cancer 76:63-72

53. Furukawa K, Kumon Y, Harada H, Kohno S, Nagato S, Teraoka M, Fujiwara S, Nakagawa K, Hamada K, Ohnishi T (2006) PTEN gene transfer suppresses the invasive potential of human malignant gliomas by regulating cell invasion-related molecules. Int J Oncol 29:73-81

54. Galli R, Binda E, Orfanelli U, Cipelletti B, Gritti A, De VS, Fiocco R, Foroni C, Dimeco F, Vescovi A (2004) Isolation and characterization of tumorigenic, stem-like neural precursors from human glioblastoma. Cancer Res 64:7011-7021

55. Ganslandt O, Stadlbauer A, Fahlbusch R, Kamada K, Buslei R, Blumcke I, Moser E, Nimsky C (2005) Proton magnetic resonance spectroscopic imaging integrated into image-guided surgery: correlation to standard magnetic resonance imaging and tumor cell density. Neurosurgery 56:291-298

56. Gardner WJ (1932) Removal of the right hemisphere for infiltrating glioma. Arch Neurol Psychiat Chic 28:470

57. Giese A, Westphal M (1996) Glioma invasion in the central nervous system. Neurosurgery 39:235-250

58. Giese A, Kluwe L, Laube B, Meissner H, Berens ME, Westphal M (1996) Migration of human glioma cells on myelin. Neurosurgery 38:755-764

59. Giese A, Bjerkvig R, Berens ME, Westphal M (2003) Cost of migration: invasion of malignant gliomas and implications for treatment. J Clin Oncol 21:1624-1636

60. Gladson CL (1999) The extracellular matrix of gliomas: modulation of cell function. J Neuropathol Exp Neurol 58:1029-1040

61. Goetz CM, Rachinger W, Decker M, Gildehaus FJ, Stocker S, Jung G, Tatsch K, Tonn JC, Reulen HJ (2005) Distribution of labelled anti-tenascin antibodies and fragments after injection into intact or partly resected C6-gliomas in rats. Cancer Immunol Immunother 54:337-344

62. Goldberg L, Kloog Y (2006) A Ras inhibitor tilts the balance between Rac and Rho and blocks phosphatidylinositol 3-kinase-dependent glioblastoma cell migration. Cancer Res 66:11709-11717

63. Goldbrunner RH, Bernstein JJ, Tonn JC (1999) Cell-extracellular matrix interaction in glioma invasion. Acta Neurochir (Wien ) 141:295-305

64. Gondi CS, Lakka SS, Dinh DH, Olivero WC, Gujrati M, Rao JS (2004) Downregulation of uPA, uPAR and MMP-9 using small, interfering, hairpin RNA (siRNA) inhibits glioma cell invasion, angiogenesis and tumor growth. Neuron Glia Biol 1:165-176

65. Grauer OM, Nierkens S, Bennink E, Toonen LW, Boon L, Wesseling P, Sutmuller RP, Adema GJ (2007) CD4+FoxP3+ regulatory $\mathrm{T}$ cells gradually accumulate in gliomas during tumor growth and efficiently suppress antiglioma immune responses in vivo. Int J Cancer 121:95-105

66. Grotegut S, von SD, Christofori G, Lehembre F (2006) Hepatocyte growth factor induces cell scattering through MAPK/Egr-1mediated upregulation of Snail. EMBO J 25:3534-3545

67. Guha A, Mukherjee J (2004) Advances in the biology of astrocytomas. Curr Opin Neurol 17:655-662 
68. Guo P, Imanishi Y, Cackowski FC, Jarzynka MJ, Tao HQ, Nishikawa R, Hirose T, Hu B, Cheng SY (2005) Up-regulation of angiopoietin-2, matrix metalloprotease-2, membrane type 1 metalloprotease, and laminin 5 gamma 2 correlates with the invasiveness of human glioma. Am J Pathol 166:877-890

69. Gupta M, Djalilvand A, Brat DJ (2005) Clarifying the diffuse gliomas: an update on the morphologic features and markers that discriminate oligodendroglioma from astrocytoma. Am J Clin Pathol 124:755-768

70. Harpold HL, Alvord EC Jr, Swanson KR (2007) The evolution of mathematical modeling of glioma proliferation and invasion. $\mathrm{J}$ Neuropathol Exp Neurol 66:1-9

71. Haubner R, Weber WA, Beer AJ, Vabuliene E, Reim D, Sarbia M, Becker KF, Goebel M, Hein R, Wester HJ, Kessler H, Schwaiger M (2005) Noninvasive visualization of the activated alphavbeta3 integrin in cancer patients by positron emission tomography and [18F]Galacto-RGD. PLoS Med 2:e70

72. Henson JW, Gaviani P, Gonzalez RG (2005) MRI in treatment of adult gliomas. Lancet Oncol 6:167-175

73. Hentschel SJ, Lang FF (2003) Current surgical management of glioblastoma. Cancer J 9:113-125

74. Higuchi M, Ohnishi T, Arita N, Hiraga S, Hayakawa T (1993) Expression of tenascin in human gliomas: its relation to histological malignancy, tumor dedifferentiation and angiogenesis. Acta Neuropathol (Berl) 85:481-487

75. Hockaday DC, Shen S, Fiveash J, Raubitschek A, Colcher D, Liu A, Alvarez V, Mamelak AN (2005) Imaging glioma extent with 131I-TM-601. J Nucl Med 46:580-586

76. Hu B, Guo P, Fang Q, Tao HQ, Wang D, Nagane M, Huang HJ, Gunji Y, Nishikawa R, Alitalo K, Cavenee WK, Cheng SY (2003) Angiopoietin-2 induces human glioma invasion through the activation of matrix metalloprotease-2. Proc Natl Acad Sci USA 100:8904-8909

77. Hynes RO (2002) Integrins: bidirectional, allosteric signaling machines. Cell 110:673-687

78. Jackson A, Kassner A, Annesley-Williams D, Reid H, Zhu XP, Li KL (2002) Abnormalities in the recirculation phase of contrast agent bolus passage in cerebral gliomas: comparison with relative blood volume and tumor grade. AJNR Am J Neuroradiol 23:7-14

79. Juliano RL (2002) Signal transduction by cell adhesion receptors and the cytoskeleton: functions of integrins, cadherins, selectins, and immunoglobulin-superfamily members. Annu Rev Pharmacol Toxicol 42:283-323

80. Keime-Guibert F, Chinot O, Taillandier L, Cartalat-Carel S, Frenay M, Kantor G, Guillamo JS, Jadaud E, Colin P, Bondiau PY, Menei P, Loiseau H, Bernier V, Honnorat J, Barrie M, Mokhtari K, Mazeron JJ, Bissery A, Delattre JY (2007) Radiotherapy for glioblastoma in the elderly. N Engl J Med 356:1527-1535

81. Kim MS, Park MJ, Kim SJ, Lee CH, Yoo H, Shin SH, Song ES, Lee SH (2005) Emodin suppresses hyaluronic acid-induced MMP-9 secretion and invasion of glioma cells. Int $\mathrm{J}$ Oncol 27:839-846

82. Kircher MF, Mahmood U, King RS, Weissleder R, Josephson L (2003) A multimodal nanoparticle for preoperative magnetic resonance imaging and intraoperative optical brain tumor delineation. Cancer Res 63:8122-8125

83. Koga K, Todaka T, Morioka M, Hamada J, Kai Y, Yano S, Okamura A, Takakura N, Suda T, Ushio Y (2001) Expression of angiopoietin-2 in human glioma cells and its role for angiogenesis. Cancer Res 61:6248-6254

84. Koochekpour S, Merzak A, Pilkington GJ (1995) Growth factors and gangliosides stimulate laminin production by human glioma cells in vitro. Neurosci Lett 186:53-56

85. Kunigal S, Gondi CS, Gujrati M, Lakka SS, Dinh DH, Olivero WC, Rao JS (2006) SPARC-induced migration of glioblastoma cell lines via uPA-uPAR signaling and activation of small GTPase RhoA. Int J Oncol 29:1349-1357

86. Kunkel P, Ulbricht U, Bohlen P, Brockmann MA, Fillbrandt R, Stavrou D, Westphal M, Lamszus K (2001) Inhibition of glioma angiogenesis and growth in vivo by systemic treatment with a monoclonal antibody against vascular endothelial growth factor receptor-2. Cancer Res 61:6624-6628

87. Kunwar S, Prados MD, Chang SM, Berger MS, Lang FF, Piepmeier JM, Sampson JH, Ram Z, Gutin PH, Gibbons RD, Aldape KD, Croteau DJ, Sherman JW, Puri RK (2007) Direct intracerebral delivery of cintredekin besudotox (IL13-PE38QQR) in recurrent malignant glioma: a report by the Cintredekin Besudotox Intraparenchymal Study Group. J Clin Oncol 25:837-844

88. Kyritsis AP, Levin VA, Yung WK, Leeds NE (1993) Imaging patterns of multifocal gliomas. Eur J Radiol 16:163-170

89. Lafitte F, Morel-Precetti S, Martin-Duverneuil N, Guermazi A, Brunet E, Heran F, Chiras J (2001) Multiple glioblastomas: CT and MR features. Eur Radiol 11:131-136

90. Lakka SS, Gondi CS, Yanamandra N, Olivero WC, Dinh DH, Gujrati M, Rao JS (2004) Inhibition of cathepsin B and MMP-9 gene expression in glioblastoma cell line via RNA interference reduces tumor cell invasion, tumor growth and angiogenesis. Oncogene 23:4681-4689

91. Lakka SS, Gondi CS, Rao JS (2005) Proteases and glioma angiogenesis. Brain Pathol 15:327-341

92. Lamszus K, Kunkel P, Westphal M (2003) Invasion as limitation to anti-angiogenic glioma therapy. Acta Neurochir Suppl 88:169-177

93. Lang FF, Gilbert MR (2006) Diffusely infiltrative low-grade gliomas in adults. J Clin Oncol 24:1236-1245

94. Lange R, Peng X, Wimmer E, Lipp M, Bernhardt G (2001) The poliovirus receptor CD155 mediates cell-to-matrix contacts by specifically binding to vitronectin. Virology 285:218-227

95. Laperriere N, Zuraw L, Cairncross G (2002) Radiotherapy for newly diagnosed malignant glioma in adults: a systematic review. Radiother Oncol 64:259-273

96. Le Bihan D, Mangin JF, Poupon C, Clark CA, Pappata S, Molko N, Chabriat H (2001) Diffusion tensor imaging: concepts and applications. J Magn Reson Imaging 13:534-546

97. Leavesley DI, Ferguson GD, Wayner EA, Cheresh DA (1992) Requirement of the integrin beta 3 subunit for carcinoma cell spreading or migration on vitronectin and fibrinogen. J Cell Biol 117:1101-1107

98. Lee J, Kotliarova S, Kotliarov Y, Li A, Su Q, Donin NM, Pastorino S, Purow BW, Christopher N, Zhang W, Park JK, Fine HA (2006) Tumor stem cells derived from glioblastomas cultured in bFGF and EGF more closely mirror the phenotype and genotype of primary tumors than do serum-cultured cell lines. Cancer Cell 9:391-403

99. Lefranc F, Brotchi J, Kiss R (2005) Possible future issues in the treatment of glioblastomas: special emphasis on cell migration and the resistance of migrating glioblastoma cells to apoptosis. J Clin Oncol 23:2411-2422

100. Li S, Gao Y, Tokuyama T, Yamamoto J, Yokota N, Yamamoto S, Terakawa S, Kitagawa M, Namba H (2007) Genetically engineered neural stem cells migrate and suppress glioma cell growth at distant intracranial sites. Cancer Lett 251:220-227

101. Lipinski CA, Tran NL, Menashi E, Rohl C, Kloss J, Bay RC, Berens ME, Loftus JC (2005) The tyrosine kinase pyk2 promotes migration and invasion of glioma cells. Neoplasia 7:435-445

102. Liu G, Yuan X, Zeng Z, Tunici P, Ng H, Abdulkadir IR, Lu L, Irvin D, Black KL, Yu JS (2006) Analysis of gene expression and chemoresistance of CD133+ cancer stem cells in glioblastoma. Mol Cancer 5:67

103. Liu M, Dai B, Kang SH, Ban K, Huang FJ, Lang FF, Aldape KD, Xie TX, Pelloski CE, Xie K, Sawaya R, Huang S (2006) FoxM1B 
is overexpressed in human glioblastomas and critically regulates the tumorigenicity of glioma cells. Cancer Res 66:3593-3602

104. Lois C, Garcia-Verdugo JM, varez-Buylla A (1996) Chain migration of neuronal precursors. Science 271:978-981

105. Louis DN, Ohgaki H, Wiestler OD, Cavenee WK (2007) WHO classification of tumours of the central nervous system. IARC, Lyon

106. Macapinlac HA (2006) Positron emission tomography of the brain. Neuroimaging Clin N Am 16:591-603, viii

107. Maglott A, Bartik P, Cosgun S, Klotz P, Ronde P, Fuhrmann G, Takeda K, Martin S, Dontenwill M (2006) The small alpha5beta 1 integrin antagonist, SJ749, reduces proliferation and clonogenicity of human astrocytoma cells. Cancer Res 66:6002-6007

108. Mapara KY, Stevenson CB, Thompson RC, Ehtesham M (2007) Stem cells as vehicles for the treatment of brain cancer. Neurosurg Clin N Am 18:71-80, ix

109. Mariani L, McDonough WS, Hoelzinger DB, Beaudry C, Kaczmarek E, Coons SW, Giese A, Moghaddam M, Seiler RW, Berens ME (2001) Identification and validation of P311 as a glioblastoma invasion gene using laser capture microdissection. Cancer Res 61:4190-4196

110. Martens T, Schmidt NO, Eckerich C, Fillbrandt R, Merchant M, Schwall R, Westphal M, Lamszus K (2006) A novel one-armed anti-c-Met antibody inhibits glioblastoma growth in vivo. Clin Cancer Res 12:6144-6152

111. Mawrin C (2005) Molecular genetic alterations in gliomatosis cerebri: what can we learn about the origin and course of the disease? Acta Neuropathol (Berl) 110:527-536

112. McComb RD, Bigner DD (1985) Immunolocalization of laminin in neoplasms of the central and peripheral nervous systems. J Neuropathol Exp Neurol 44:242-253

113. McDonough WS, Tran NL, Berens ME (2005) Regulation of glioma cell migration by serine-phosphorylated P311. Neoplasia 7:862-872

114. McKnight TR, von dem Bussche MH, Vigneron DB, Lu Y, Berger MS, McDermott MW, Dillon WP, Graves EE, Pirzkall A, Nelson SJ (2002) Histopathological validation of a three-dimensional magnetic resonance spectroscopy index as a predictor of tumor presence. J Neurosurg 97:794-802

115. Mellinghoff IK, Wang MY, Vivanco I, Haas-Kogan DA, Zhu S, Dia EQ, Lu KV, Yoshimoto K, Huang JH, Chute DJ, Riggs BL, Horvath S, Liau LM, Cavenee WK, Rao PN, Beroukhim R, Peck TC, Lee JC, Sellers WR, Stokoe D, Prados M, Cloughesy TF, Sawyers CL, Mischel PS (2005) Molecular determinants of the response of glioblastomas to EGFR kinase inhibitors. N Engl J Med 353:2012-2024

116. Mijatovic S, Maksimovic-Ivanic D, Radovic J, Miljkovic D, Harhaji L, Vuckovic O, Stosic-Grujicic S, Mostarica SM, Trajkovic V (2005) Anti-glioma action of aloe emodin: the role of ERK inhibition. Cell Mol Life Sci 62:589-598

117. Mitra SK, Hanson DA, Schlaepfer DD (2005) Focal adhesion kinase: in command and control of cell motility. Nat Rev Mol Cell Biol 6:56-68

118. Murad GJ, Walbridge S, Morrison PF, Garmestani K, Degen JW, Brechbiel MW, Oldfield EH, Lonser RR (2006) Real-time, image-guided, convection-enhanced delivery of interleukin 13 bound to pseudomonas exotoxin. Clin Cancer Res 12:31453151

119. Murad GJ, Walbridge S, Morrison PF, Szerlip N, Butman JA, Oldfield EH, Lonser RR (2007) Image-guided convectionenhanced delivery of gemcitabine to the brainstem. J Neurosurg 106:351-356

120. Murai T, Miyazaki Y, Nishinakamura H, Sugahara KN, Miyauchi T, Sako Y, Yanagida T, Miyasaka M (2004) Engagement of CD44 promotes Rac activation and CD44 cleavage during tumor cell migration. J Biol Chem 279:4541-4550
121. Nakada M, Niska JA, Miyamori H, McDonough WS, Wu J, Sato H, Berens ME (2004) The phosphorylation of EphB2 receptor regulates migration and invasion of human glioma cells. Cancer Res 64:3179-3185

122. Nakada M, Drake KL, Nakada S, Niska JA, Berens ME (2006) Ephrin-B3 ligand promotes glioma invasion through activation of Rac1. Cancer Res 66:8492-8500

123. Nakamura JL (2007) The epidermal growth factor receptor in malignant gliomas: pathogenesis and therapeutic implications. Expert Opin Ther Targets 11:463-472

124. Nobes CD, Hall A (1999) Rho GTPases control polarity, protrusion, and adhesion during cell movement. J Cell Biol 144:1235-1244

125. Owens GC, Orr EA, DeMasters BK, Muschel RJ, Berens ME, Kruse CA (1998) Overexpression of a transmembrane isoform of neural cell adhesion molecule alters the invasiveness of rat CNS1 glioma. Cancer Res 58:2020-2028

126. Patel SJ, Shapiro WR, Laske DW, Jensen RL, Asher AL, Wessels BW, Carpenter SP, Shan JS (2005) Safety and feasibility of convection-enhanced delivery of Cotara for the treatment of malignant glioma: initial experience in 51 patients. Neurosurgery 56:1243-1252

127. Paulus W, Huettner C, Tonn JC (1994) Collagens, integrins and the mesenchymal drift in glioblastomas: a comparison of biopsy specimens, spheroid and early monolayer cultures. Int J Cancer 58:841-846

128. Pedersen PH, Marienhagen K, Mork S, Bjerkvig R (1993) Migratory pattern of fetal rat brain cells and human glioma cells in the adult rat brain. Cancer Res 53:5158-5165

129. Peiffer J, Kleihues P (1999) Hans-Joachim Scherer (1906-1945), pioneer in glioma research. Brain Pathol 9:241-245

130. Pilkington CJ (1996) The role of the extracellular matrix in neoplastic glial invasion of the nervous system. Braz J Med Biol Res 29:1159-1172

131. Pirotte B, Goldman S, Dewitte O, Massager N, Wikler D, Lefranc F, Ben Taib NO, Rorive S, David P, Brotchi J, Levivier M (2006) Integrated positron emission tomography and magnetic resonance imaging-guided resection of brain tumors: a report of 103 consecutive procedures. J Neurosurg 104:238-253

132. Pirzkall A, McKnight TR, Graves EE, Carol MP, Sneed PK, Wara WW, Nelson SJ, Verhey LJ, Larson DA (2001) MR-spectroscopy guided target delineation for high-grade gliomas. Int $\mathbf{J}$ Radiat Oncol Biol Phys 50:915-928

133. Pollard TD, Borisy GG (2003) Cellular motility driven by assembly and disassembly of actin filaments. Cell 112:453-465

134. Popperl G, Kreth FW, Herms J, Koch W, Mehrkens JH, Gildehaus FJ, Kretzschmar HA, Tonn JC, Tatsch K (2006) Analysis of $18 \mathrm{~F}-\mathrm{FET}$ PET for grading of recurrent gliomas: is evaluation of uptake kinetics superior to standard methods? J Nucl Med 47:393-403

135. Provenzale JM, Mukundan S, Barboriak DP (2006) Diffusionweighted and perfusion MR imaging for brain tumor characterization and assessment of treatment response. Radiology 239:632-649

136. Raghavan R, Brady ML, Rodriguez-Ponce MI, Hartlep A, Pedain C, Sampson JH (2006) Convection-enhanced delivery of therapeutics for brain disease, and its optimization. Neurosurg Focus 20:E12

137. Rao JS (2003) Molecular mechanisms of glioma invasiveness: the role of proteases. Nat Rev Cancer 3:489-501

138. Raza SM, Lang FF, Aggarwal BB, Fuller GN, Wildrick DM, Sawaya R (2002) Necrosis and glioblastoma: a friend or a foe? A review and a hypothesis. Neurosurgery 51:2-12

139. Reardon DA, Akabani G, Coleman RE, Friedman AH, Friedman HS, Herndon JE, McLendon RE, Pegram CN, Provenzale JM, Quinn JA, Rich JN, Vredenburgh JJ, Desjardins A, Gururangan S, Badruddoja $\mathrm{M}$, Dowell JM, Wong TZ, Zhao XG, Za- 
lutsky MR, Bigner DD (2006) Salvage radioimmunotherapy with murine iodine-131-labeled antitenascin monoclonal antibody $81 \mathrm{C} 6$ for patients with recurrent primary and metastatic malignant brain tumors: phase II study results. J Clin Oncol 24:115-122

140. Reardon DA, Rich JN, Friedman HS, Bigner DD (2006) Recent advances in the treatment of malignant astrocytoma. J Clin Oncol 24:1253-1265

141. Rees J (2003) Advances in magnetic resonance imaging of brain tumours. Curr Opin Neurol 16:643-650

142. Ridley AJ, Schwartz MA, Burridge K, Firtel RA, Ginsberg MH, Borisy G, Parsons JT, Horwitz AR (2003) Cell migration: integrating signals from front to back. Science 302:1704-1709

143. Roggendorf W, Strupp S, Paulus W (1996) Distribution and characterization of microglia/macrophages in human brain tumors. Acta Neuropathol (Berl) 92:288-293

144. Rollins KE, Kleinschmidt-DeMasters BK, Corboy JR, Damek DM, Filley CM (2005) Lymphomatosis cerebri as a cause of white matter dementia. Hum Pathol 36:282-290

145. Rubin JB, Kung AL, Klein RS, Chan JA, Sun Y, Schmidt K, Kieran MW, Luster AD, Segal RA (2003) A small-molecule antagonist of CXCR4 inhibits intracranial growth of primary brain tumors. Proc Natl Acad Sci USA 100:13513-13518

146. Sahai E (2005) Mechanisms of cancer cell invasion. Curr Opin Genet Dev 15:87-96

147. Sakariassen PO, Prestegarden L, Wang J, Skaftnesmo KO, Mahesparan R, Molthoff C, Sminia P, Sundlisaeter E, Misra A, Tysnes BB, Chekenya M, Peters H, Lende G, Kalland KH, Oyan AM, Petersen K, Jonassen I, van der KA, Feuerstein BG, Terzis AJ, Bjerkvig R, Enger PO (2006) Angiogenesis-independent tumor growth mediated by stem-like cancer cells. Proc Natl Acad Sci USA 103:16466-16471

148. Salhia B, Tran NL, Symons M, Winkles JA, Rutka JT, Berens ME (2006) Molecular pathways triggering glioma cell invasion. Expert Rev Mol Diagn 6:613-626

149. Salvati M, Caroli E, Orlando ER, Frati A, Artizzu S, Ferrante L (2003) Multicentric glioma: our experience in 25 patients and critical review of the literature. Neurosurg Rev 26:275-279

150. Sampson JH, Akabani G, Archer GE, Bigner DD, Berger MS, Friedman AH, Friedman HS, Herndon JE, Kunwar S, Marcus S, McLendon RE, Paolino A, Penne K, Provenzale J, Quinn J, Reardon DA, Rich J, Stenzel T, Tourt-Uhlig S, Wikstrand C, Wong T, Williams R, Yuan F, Zalutsky MR, Pastan I (2003) Progress report of a Phase I study of the intracerebral microinfusion of a recombinant chimeric protein composed of transforming growth factor (TGF)-alpha and a mutated form of the Pseudomonas exotoxin termed PE-38 (TP-38) for the treatment of malignant brain tumors. J Neurooncol 65:27-35

151. Sampson JH, Brady ML, Petry NA, Croteau D, Friedman AH, Friedman HS, Wong T, Bigner DD, Pastan I, Puri RK, Pedain C (2007) Intracerebral infusate distribution by convection-enhanced delivery in humans with malignant gliomas: descriptive effects of target anatomy and catheter positioning. Neurosurgery 60:ONS89-ONS98

152. Sanai N, varez-Buylla A, Berger MS (2005) Neural stem cells and the origin of gliomas. N Engl J Med 353:811-822

153. Sarkar S, Nuttall RK, Liu S, Edwards DR, Yong VW (2006) Tenascin-C stimulates glioma cell invasion through matrix metalloproteinase-12. Cancer Res 66:11771-11780

154. Sarkaria JN, Carlson BL, Schroeder MA, Grogan P, Brown PD, Giannini C, Ballman KV, Kitange GJ, Guha A, Pandita A, James CD (2006) Use of an orthotopic xenograft model for assessing the effect of epidermal growth factor receptor amplification on glioblastoma radiation response. Clin Cancer Res 12:2264-2271

155. Sasaki H, Yoshida K, Ikeda E, Asou H, Inaba M, Otani M, Kawase T (1998) Expression of the neural cell adhesion molecule in astrocytic tumors: an inverse correlation with malignancy. Cancer 82:1921-1931

156. Sawaya RE, Yamamoto M, Gokaslan ZL, Wang SW, Mohanam S, Fuller GN, McCutcheon IE, Stetler-Stevenson WG, Nicolson GL, Rao JS (1996) Expression and localization of $72 \mathrm{kDa}$ type IV collagenase (MMP-2) in human malignant gliomas in vivo. Clin Exp Metastasis 14:35-42

157. Scherer HJ (1938) Structural development in gliomas. Am J Cancer 34:333-351

158. Senner V, Schmidtpeter S, Braune S, Puttmann S, Thanos S, Bartsch U, Schachner M, Paulus W (2003) AMOG/beta2 and glioma invasion: does loss of AMOG make tumour cells run amok? Neuropathol Appl Neurobiol 29:370-377

159. Shah AC, Benos D, Gillespie GY, Markert JM (2003) Oncolytic viruses: clinical applications as vectors for the treatment of malignant gliomas. J Neurooncol 65:203-226

160. Shi Q, Bao S, Song L, Wu Q, Bigner DD, Hjelmeland AB, Rich JN (2007) Targeting SPARC expression decreases glioma cellular survival and invasion associated with reduced activities of FAK and ILK kinases. Oncogene 26:4084-4094

161. Shi Q, Hjelmeland AB, Keir ST, Song L, Wickman S, Jackson D, Ohmori O, Bigner DD, Friedman HS, Rich JN (2007) A novel low-molecular weight inhibitor of focal adhesion kinase, TAE226, inhibits glioma growth. Mol Carcinog 46(6):488-496

162. Singh SK, Clarke ID, Terasaki M, Bonn VE, Hawkins C, Squire J, Dirks PB (2003) Identification of a cancer stem cell in human brain tumors. Cancer Res 63:5821-5828

163. Singh SK, Hawkins C, Clarke ID, Squire JA, Bayani J, Hide T, Henkelman RM, Cusimano MD, Dirks PB (2004) Identification of human brain tumour initiating cells. Nature 432:396-401

164. Sloan KE, Eustace BK, Stewart JK, Zehetmeier C, Torella C, Simeone M, Roy JE, Unger C, Louis DN, Ilag LL, Jay DG (2004) CD155/PVR plays a key role in cell motility during tumor cell invasion and migration. BMC Cancer 4:73

165. Sloan KE, Stewart JK, Treloar AF, Matthews RT, Jay DG (2005) CD155/PVR enhances glioma cell dispersal by regulating adhesion signaling and focal adhesion dynamics. Cancer Res 65:10930-10937

166. Smith JS, Cha S, Mayo MC, McDermott MW, Parsa AT, Chang SM, Dillon WP, Berger MS (2005) Serial diffusion-weighted magnetic resonance imaging in cases of glioma: distinguishing tumor recurrence from postresection injury. J Neurosurg 103:428-438

167. Sonabend AM, Ulasov IV, Han Y, Lesniak MS (2006) Oncolytic adenoviral therapy for glioblastoma multiforme. Neurosurg Focus 20:E19

168. Song SW, Fuller GN, Khan A, Kong S, Shen W, Taylor E, Ramdas L, Lang FF, Zhang W (2003) IIp45, an insulin-like growth factor binding protein 2 (IGFBP-2) binding protein, antagonizes IGFBP-2 stimulation of glioma cell invasion. Proc Natl Acad Sci USA 100:13970-13975

169. Song SW, Fuller GN, Zheng H, Zhang W (2005) Inactivation of the invasion inhibitory gene IIp45 by alternative splicing in gliomas. Cancer Res 65:3562-3567

170. Stummer W, Pichlmeier U, Meinel T, Wiestler OD, Zanella F, Reulen HJ (2006) Fluorescence-guided surgery with 5-aminolevulinic acid for resection of malignant glioma: a randomised controlled multicentre phase III trial. Lancet Oncol 7:392-401

171. Stupp R, Mason WP, van den Bent MJ, Weller M, Fisher B, Taphoorn MJ, Belanger K, Brandes AA, Marosi C, Bogdahn U, Curschmann J, Janzer RC, Ludwin SK, Gorlia T, Allgeier A, Lacombe D, Cairncross JG, Eisenhauer E, Mirimanoff RO (2005) Radiotherapy plus concomitant and adjuvant temozolomide for glioblastoma. N Engl J Med 352:987-996

172. Subramanian A, Harris A, Piggott K, Shieff C, Bradford R (2002) Metastasis to and from the central nervous system-the 'relatively protected site'. Lancet Oncol 3:498-507 
173. Sugahara T, Korogi Y, Kochi M, Ikushima I, Hirai T, Okuda T, Shigematsu Y, Liang L, Ge Y, Ushio Y, Takahashi M (1998) Correlation of MR imaging-determined cerebral blood volume maps with histologic and angiographic determination of vascularity of gliomas. AJR Am J Roentgenol 171:1479-1486

174. Suzuki M, Suzuki M, Nakayama J, Suzuki A, Angata K, Chen S, Sakai K, Hagihara K, Yamaguchi Y, Fukuda M (2005) Polysialic acid facilitates tumor invasion by glioma cells. Glycobiology $15: 887-894$

175. Taga T, Suzuki A, Gonzalez-Gomez I, Gilles FH, Stins M, Shimada H, Barsky L, Weinberg KI, Laug WE (2002) alpha v-Integrin antagonist EMD 121974 induces apoptosis in brain tumor cells growing on vitronectin and tenascin. Int J Cancer 98:690-697

176. Tate AR, Underwood J, Acosta DM, Julia-Sape M, Majos C, Moreno-Torres A, Howe FA, van der Graaf M, Lefournier V, Murphy MM, Loosemore A, Ladroue C, Wesseling P, Luc Bosson J, Cabanas ME, Simonetti AW, Gajewicz W, Calvar J, Capdevila A, Wilkins PR, Bell BA, Remy C, Heerschap A, Watson D, Griffiths JR, Arus C (2006) Development of a decision support system for diagnosis and grading of brain tumours using in vivo magnetic resonance single voxel spectra. NMR Biomed 19:411-434

177. Tonn JC, Kerkau S, Hanke A, Bouterfa H, Mueller JG, Wagner S, Vince GH, Roosen K (1999) Effect of synthetic matrix-metalloproteinase inhibitors on invasive capacity and proliferation of human malignant gliomas in vitro. Int J Cancer 80:764-772

178. Tran NL, McDonough WS, Savitch BA, Fortin SP, Winkles JA, Symons M, Nakada M, Cunliffe HE, Hostetter G, Hoelzinger DB, Rennert JL, Michaelson JS, Burkly LC, Lipinski CA, Loftus JC, Mariani L, Berens ME (2006) Increased fibroblast growth factorinducible 14 expression levels promote glioma cell invasion via Rac1 and nuclear factor- $\{$ kappa $\}$ B and correlate with poor patient outcome. Cancer Res 66:9535-9542

179. Tysnes BB, Mahesparan R (2001) Biological mechanisms of glioma invasion and potential therapeutic targets. J Neurooncol 53:129-147

180. Uhm JH, Dooley NP, Kyritsis AP, Rao JS, Gladson CL (1999) Vitronectin, a glioma-derived extracellular matrix protein, protects tumor cells from apoptotic death. Clin Cancer Res 5:1587-1594

181. Ulmer S, Braga TA, Barker FG, Lev MH, Gonzalez RG, Henson JW (2006) Clinical and radiographic features of peritumoral infarction following resection of glioblastoma. Neurology 67:1668-1670

182. van den Bent MJ, Chinot O, Boogerd W, Bravo MJ, Taphoorn MJ, Kros JM, van der Rijt CC, Vecht CJ, De BN, Baron B (2003) Second-line chemotherapy with temozolomide in recurrent oligodendroglioma after PCV (procarbazine, lomustine and vincristine) chemotherapy: EORTC Brain Tumor Group phase II study 26972. Ann Oncol 14:599-602

183. Vandergrift WA, Patel SJ, Nicholas JS, Varma AK (2006) Convection-enhanced delivery of immunotoxins and radioisotopes for treatment of malignant gliomas. Neurosurg Focus 20:E13

184. Veiseh O, Sun C, Gunn J, Kohler N, Gabikian P, Lee D, Bhattarai N, Ellenbogen R, Sze R, Hallahan A, Olson J, Zhang M (2005) Optical and MRI multifunctional nanoprobe for targeting gliomas. Nano Lett 5:1003-1008

185. Vescovi AL, Galli R, Reynolds BA (2006) Brain tumour stem cells. Nat Rev Cancer 6:425-436

186. Wang H, Wang H, Shen W, Huang H, Hu L, Ramdas L, Zhou YH, Liao WS, Fuller GN, Zhang W (2003) Insulin-like growth factor binding protein 2 enhances glioblastoma invasion by activating invasion-enhancing genes. Cancer Res $63: 4315-4321$
187. Wang L, Zhang ZG, Zhang RL, Gregg SR, Hozeska-Solgot A, LeTourneau Y, Wang Y, Chopp M (2006) Matrix metalloproteinase 2 (MMP2) and MMP9 secreted by erythropoietin-activated endothelial cells promote neural progenitor cell migration. J Neurosci 26:5996-6003

188. Watters JJ, Schartner JM, Badie B (2005) Microglia function in brain tumors. J Neurosci Res 81:447-455

189. Weaver JD, Vinters HV, Koretz B, Xiong Z, Mischel P, Kado D (2007) Lymphomatosis cerebri presenting as rapidly progressive dementia. Neurologist 13:150-153

190. Weaver M, Laske DW (2003) Transferrin receptor ligand-targeted toxin conjugate (Tf-CRM107) for therapy of malignant gliomas. J Neurooncol 65:3-13

191. Wesseling P, van der Laak JA, de Leeuw H, Ruiter DJ, Burger PC (1994) Quantitative immunohistological analysis of the microvasculature in untreated human glioblastoma multiforme. Computer-assisted image analysis of whole-tumor sections. J Neurosurg 81:902-909

192. Wesseling P, van der Laak JA, Link M, Teepen HL, Ruiter DJ (1998) Quantitative analysis of microvascular changes in diffuse astrocytic neoplasms with increasing grade of malignancy. Hum Pathol 29:352-358

193. Wick W, Platten M, Weller M (2001) Glioma cell invasion: regulation of metalloproteinase activity by TGF-beta. J Neurooncol 53:177-185

194. Widera D, Mikenberg I, Kaltschmidt B, Kaltschmidt C (2006) Potential role of NF-kappaB in adult neural stem cells: the underrated steersman? Int J Dev Neurosci 24:91-102

195. Wu M, Chen Q, Li D, Li X, Li X, Huang C, Tang Y, Zhou Y, Wang D, Tang K, Cao L, Shen S, Li G (2007) LRRC4 inhibits human glioblastoma cells proliferation, invasion, and proMMP-2 activation by reducing SDF-1alpha/CXCR4-mediated ERK1/2 and Akt signaling pathways. J Cell Biochem. doi:10.1002/ jcp. 21163

196. Yamada S, Bu XY, Khankaldyyan V, Gonzales-Gomez I, McComb JG, Laug WE (2006) Effect of the angiogenesis inhibitor Cilengitide (EMD 121974) on glioblastoma growth in nude mice. Neurosurgery 59:1304-1312

197. Yip S, Sabetrasekh R, Sidman RL, Snyder EY (2006) Neural stem cells as novel cancer therapeutic vehicles. Eur J Cancer 42:1298-1308

198. Yong VW, Power C, Forsyth P, Edwards DR (2001) Metalloproteinases in biology and pathology of the nervous system. Nat Rev Neurosci 2:502-511

199. Yuan X, Curtin J, Xiong Y, Liu G, Waschsmann-Hogiu S, Farkas DL, Black KL, Yu JS (2004) Isolation of cancer stem cells from adult glioblastoma multiforme. Oncogene 23:9392-9400

200. Yuh WT, Nguyen HD, Tali ET, Mayr NA, Fisher DJ, Atlas SW, Carvlin MC, Drayer BP, Pollei SR, Runge VM (1994) Delineation of gliomas with various doses of MR contrast material. AJNR Am J Neuroradiol 15:983-989

201. Zagzag D, Friedlander DR, Margolis B, Grumet M, Semenza GL, Zhong H, Simons JW, Holash J, Wiegand SJ, Yancopoulos GD (2000) Molecular events implicated in brain tumor angiogenesis and invasion. Pediatr Neurosurg 33:49-55

202. Zagzag D, Shiff B, Jallo GI, Greco MA, Blanco C, Cohen H, Hukin J, Allen JC, Friedlander DR (2002) Tenascin-C promotes microvascular cell migration and phosphorylation of focal adhesion kinase. Cancer Res 62:2660-2668

203. Zagzag D, Salnikow K, Chiriboga L, Yee H, Lan L, Ali MA, Garcia R, Demaria S, Newcomb EW (2005) Downregulation of major histocompatibility complex antigens in invading glioma cells: stealth invasion of the brain. Lab Invest 85:328-341

204. Zamecnik J (2005) The extracellular space and matrix of gliomas. Acta Neuropathol (Berl) 110:435-442 